\title{
Erratum: Traditional Chinese medicine and new concepts of predictive, preventive and personalised medicine in diagnosis and treatment of sub-optimal health
}

Wei Wang ${ }^{1,2^{*}}$, Alyce Russell ${ }^{1}$, Yuxiang Yan ${ }^{2^{*}}$ and on behalf of Global Health Epidemiology Reference Group (GHERG)

\section{Erratum}

Following publication of our article [1] we noticed that we included the incorrect version of figure two (Figure 1 here) representing the 5 domains of suboptimal health. We have provided the correct figure here.

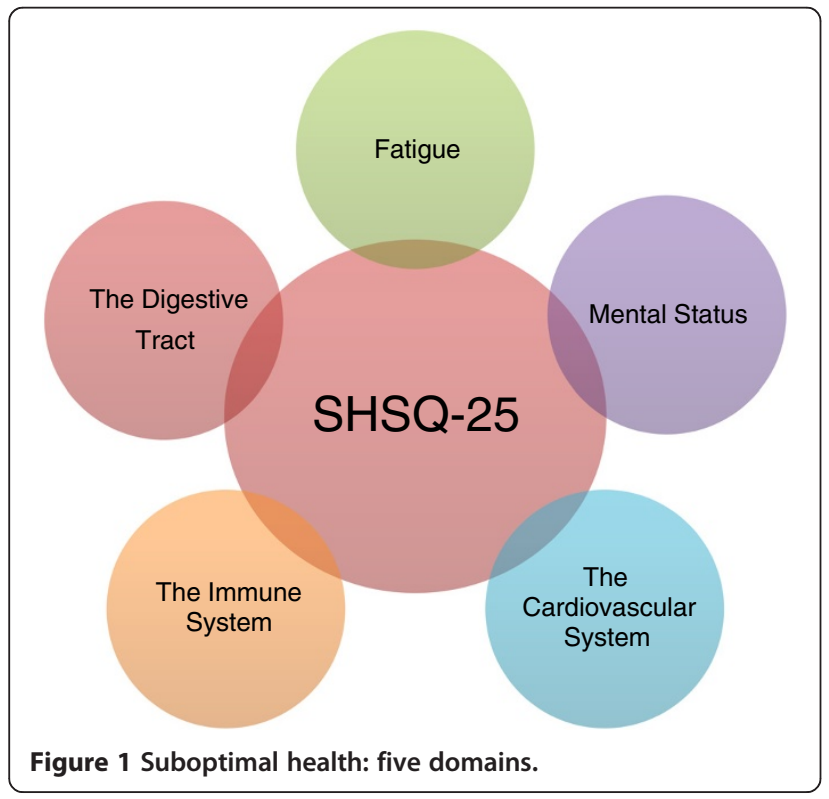

* Correspondence: wei.wang@ecu.edu.au; yanyxepi@ccmu.edu.cn

'School of Medical Sciences, Edith Cowan University, Perth, Western Australia WA6027, Australia

${ }^{2}$ Municipal Key Laboratory of Clinical Epidemiology, School of Public Health, Capital Medical University, Beijing 100069, China
We would also like to clarify that the data presented in tables $1-5$ in the article [1] have previously been published in our earlier article [2]. The recent article uses the original data but provides a new interpretation based on the innovative paradigm of predictive, preventive and personalized medicine. The authors apologise for not clearly stating this in our recent article and for any confusion caused.

Received: 31 July 2014 Accepted: 1 August 2014

Published: 26 August 2014

\section{References}

1. Wang W, Russell A, Yan YX, on behalf of Global Health Epidemiology Reference Group (GHERG): Traditional Chinese medicine and new concepts of predictive, preventive and personalized medicine in diagnosis and treatment of suboptimal health. EPMA Journal 2014, 5:4. 13 February 2014.

2. Wang $W$, Yan YX: Suboptimal health: a new health dimension for translational medicine. Clin Transl Med 2012, 1:28.

doi:10.1186/1878-5085-5-12

Cite this article as: Wang et al:: Erratum: Traditional Chinese medicine and new concepts of predictive, preventive and personalised medicine in diagnosis and treatment of sub-optimal health. The EPMA Journal 2014 5:12.

\section{Submit your next manuscript to BioMed Central and take full advantage of:}

- Convenient online submission

- Thorough peer review

- No space constraints or color figure charges

- Immediate publication on acceptance

- Inclusion in PubMed, CAS, Scopus and Google Scholar

- Research which is freely available for redistribution

\section{Ciomed Central}

(c) 2014 Wang et al.; licensee BioMed Central Ltd. This is an Open Access article distributed under the terms of the Creative Commons Attribution License (http://creativecommons.org/licenses/by/4.0), which permits unrestricted use, distribution, and reproduction in any medium, provided the original work is properly credited. The Creative Commons Public Domain Dedication waiver (http://creativecommons.org/publicdomain/zero/1.0/) applies to the data made available in this article, unless otherwise stated. 